\title{
Current role in facial allograft transplantation: what have we learned?
}

\author{
Pedro Infante-Cossio1, Fernando Barrera-Pulido², Tomas Gomez-Cia², Domingo \\ Sicilia-Castro², Alberto Garcia-Perla-Garcia', Purificacion Gacto-Sanchez ${ }^{2}$, Jose- \\ Maria Hernandez-Guisado', Araceli Lagares-Borrego², Rocio Narros-Gimenez², \\ Juan-David Gonzalez-Padilla ${ }^{1}$
}

${ }^{1}$ Department of Oral and Maxillofacial Surgery, Virgen del Rocio University Hospital, 41013 Seville, Spain.

${ }^{2}$ Department of Plastic and Reconstructive Surgery, Virgen del Rocio University Hospital, 41013 Seville, Spain.

Address for correspondence: Dr. Pedro Infante-Cossio, Department of Oral and Maxillofacial Surgery, Virgen del Rocio University Hospital, Av. Manuel Siurot, 41013 Seville, Spain. E-mail: pinfante@us.es

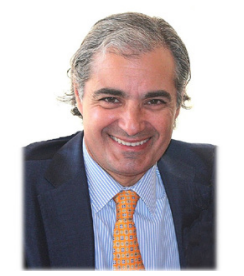

Dr. Pedro Infante-Cossio, M.D., D.D.S., Ph.D., received both his medical and dental degree from the University of Seville, Spain. He obtained his $\mathrm{PhD}$ degree and received his Oral and Maxillofacial Surgery training at the Virgen del Rocio University Hospital, Seville, Spain. From 1994 he has been consultant in Oral and Maxillofacial Surgery at the Virgen del Rocio University Hospital, Seville, Spain. Currently, he is Full Professor in Oral and Maxillofacial Surgery at the Faculty of Medicine and Dentistry in Seville, Spain.

\section{ABSTRACT}

Face transplant (FT) has evolved enormously in the last 10 years since the successful completion of the first facial transplant. This procedure has become a new reconstructive option for complex facial deformities to restore the anatomy of patients with severely disfigured faces. The authors review the literature and discuss the main surgical, immunological, and ethical aspects as well as the results described in patients undergoing FT. To date there have been more than thirty FT worldwide. The main indication was post-traumatic deformity. In all cases a standard immunosuppression was performed with three drugs, although acute rejection episodes were observed, that could be controlled with conventional immunosuppressive regimen. Overall, functional and aesthetic results have been excellent at short-term and high satisfaction rate exceeded initial expectations, although long-term data are still scarce. Major complications were opportunistic infections. Five deaths that occurred have reopened the ethical debate about the potential complications and concerns of providing informed consent to recipients. Continuous progresses in microsurgical techniques and preoperative planning have promoted the evolution from partial to full FT. All these are on the basis of accurate and careful selection of wellmotivated candidates. The next challenge will be getting new immunosuppressive treatment strategies. Although clinical experience has demonstrated the FT viability, it is still considered an experimental procedure in which we have much to learn to define its true role in the current reconstructive surgery and resolve major technical, medical and ethical problems involved.

Key words:

Face transplantation; composite tissue transplantation; facial allograft transplantation; facial reconstruction; outcomes and complications of face transplantation

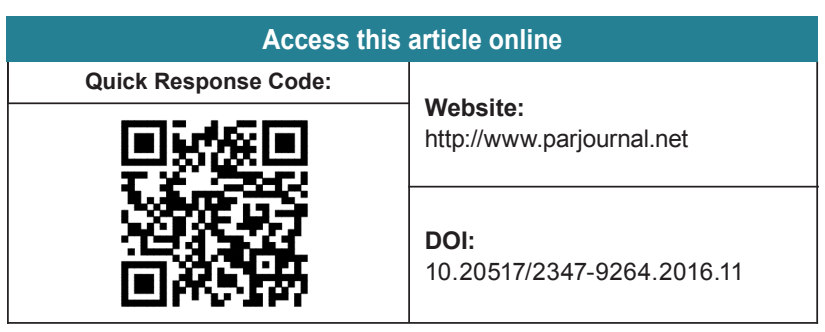

C 2016 Plastic and Aesthetic Research | Published by OAE Publishing Inc.
This is an open access article distributed under the terms of the Creative Commons Attribution-NonCommercial-ShareAlike 3.0 License, which allows others to remix, tweak and build upon the work non-commercially, as long as the author is credited and the new creations are licensed under the identical terms.

For reprints contact: service@oaepublish.com

How to cite this article: Infante-Cossio P, Barrera-Pulido F, GomezCia T, Sicilia-Castro D, Garcia-Perla-Garcia A, Gacto-Sanchez P, Hernandez-Guisado JM, Lagares-Borrego A, Narros-Gimenez R, Gonzalez-Padilla JD. Current role in facial allograft transplantation: what have we learned? Plast Aesthet Res 2016;3:211-8.

Received: 28-03-2016; Accepted: 14-04-2016

2016 Plastic and Aesthetic Research | Published by OAE Publishing Inc. 


\section{INTRODUCTION}

Face transplant (FT) has evolved enormously in the last 10 years since the successful completion of the first facial transplant allograft (FAT) in November 2005 in Amiens (France). ${ }^{[1]}$ However, scientific community must be cautious because there are scarcely few selected cases in clinical follow-up after a decade of clinical experience. In a literature search in English from the PubMed/Medline data base (http://www.ncbi.nlm.nih.gov/PubMed), with the following search terms: "face", "facial", "transplant", "transplantation", "composite allotransplant tissue" and "vascularized composite allotransplant", there have been reported clinical data from 31 patients to date [Figures 1 and 2]..$^{[2,3]}$ Although the comparative analysis of data reported in these early clinical cases shows that overall functional and aesthetic results in FT are encouraging, there are still many unresolved aspects of experimental research and clinical application to know the real extent and the true dimension of this procedure. This paper will review, point by point, major surgical, immunological, ethical, and clinical follow-up aspects on FAT published in the literature, from the analysis of the results reported by pioneer FT teams on patients operated to date.

\section{SURGICAL CONSIDERATIONS}

\section{Preclinical models}

The initial problem on the knowledge of FT is common to other body transplants: to provide a basis for the study of the surgical technique. That is why in recent years, worldwide FT transplant teams have developed different preclinical research in experimental surgery on animals and cadaveric models. The pioneer teams have emphasized the importance on this preclinical work prior for the completion of a successful clinical transplantation. ${ }^{[4,5]}$ FAT is a new field in reconstructive surgery that is still considered as an experimental and exceptional procedure. Therefore, it is imperative to establish a protocol and a previous training to achieve excellence in this demanding procedure, to know perfectly the anatomy of the allograft needed in each case, and to handle the tissues that compound the allograft.

The non-human primate model is the best suited since it provides tissues of anatomical size and texture very similar to humans. ${ }^{[6-9]}$ Other models used have been rats, ${ }^{[10-14]}$ rabbits and $\operatorname{dogs},{ }^{[15,16]}$ animals that are easy to use in a research center [Figure 3]..$^{[17,18]}$

Preclinical studies on cadavers have sought to find the best way to recover soft and hard tissues, muscles, nerves and vessels of donor face while reducing tissue ischemia to the minimum. Studies on cadavers have been performed with recovery simulations of lower, middle and/or upper third face for FAT preparation ${ }^{[19-23]}$ and development either partial or total. ${ }^{[4,5,24-26]}$ Preclinical planning studies for implementation and validation of tools for planning, design and adaptation of allograft into recipients are other key

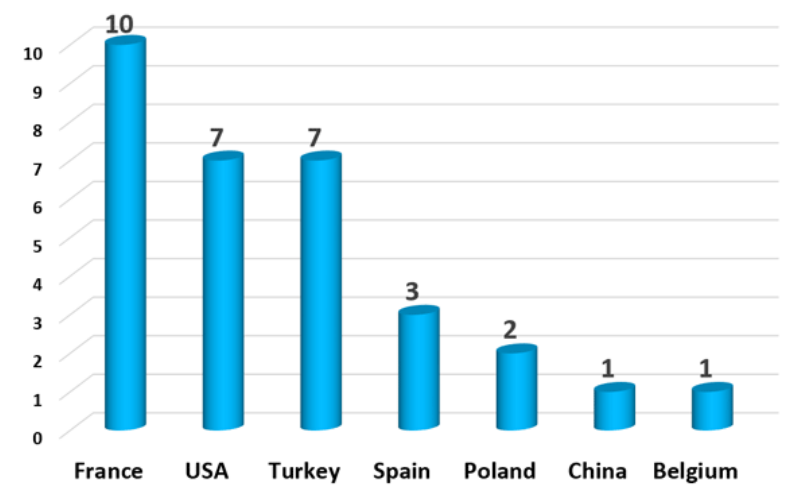

Figure 1: Countries in which a face transplant had been made in the last decade

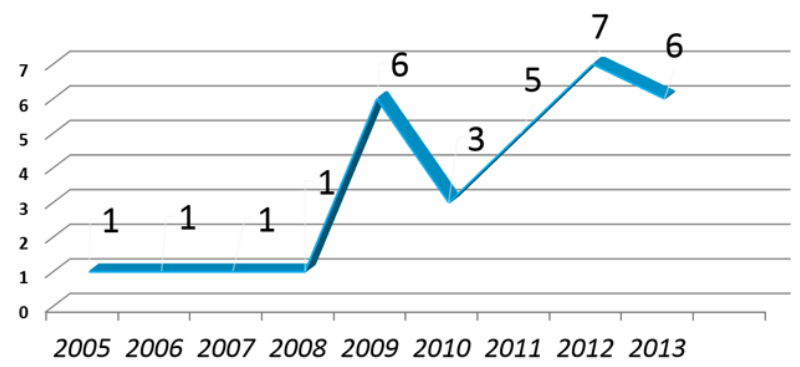

Figure 2: Evolution of the number of face transplant in the last decade
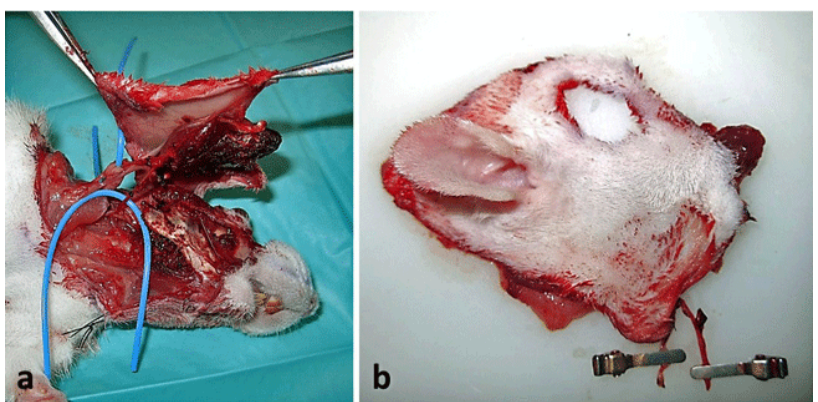

Figure 3: Design of a facial transplant allograft in a Wistar rat. (a) Allograft pedicled in the external jugular vein and common carotid artery; (b) external view of the allograft before anastomosis

aspects for anatomical structures of donors and recipients are consistent in size and configuration to allow a reasonable accommodation. Anthropometric study of facial soft and hard tissues both the donor and the recipient must be as accurate as possible to ensure the viability of the procedure and the proper insertion of the allograft into the defect, ${ }^{\text {[27-29] }}$ even including the preparation of preoperative surgical osteotomy guides. ${ }^{[30-32]}$

\section{Overall aspects on surgery}

In FAT, microsurgical procedures are similar to those other complex reconstructive surgical procedures of the face. ${ }^{[33,34]}$ The crux here is based on the exact surgical planning and surgical execution considering to ensure the adequate perfusion and blood supply allograft, knowledge of angiosomes, and vascularity of facial tissues. Allografts are recovered from the donor in monobloc containing the facial osteomiocutaneous tissues with mimic muscles, vessels and motor and sensory 

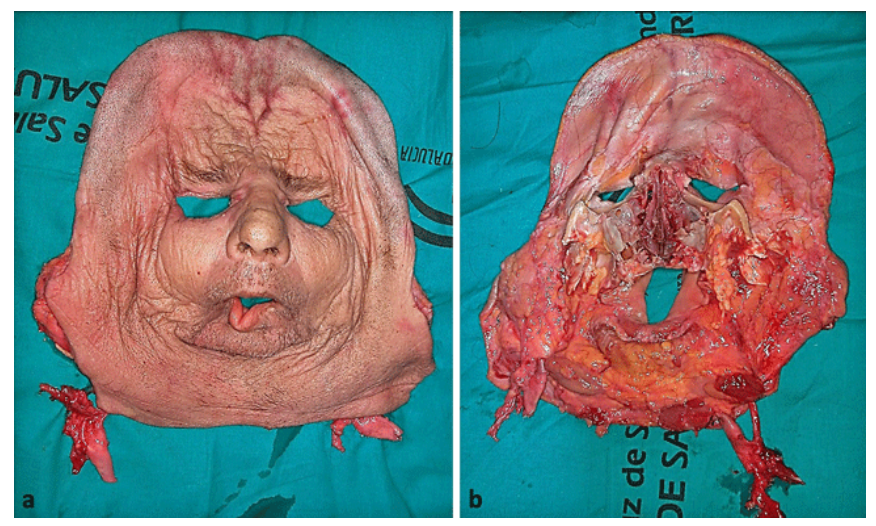

Figure 4: Experimental model of a full face transplant in cadaver. (a) External and (b) internal view of the allograft

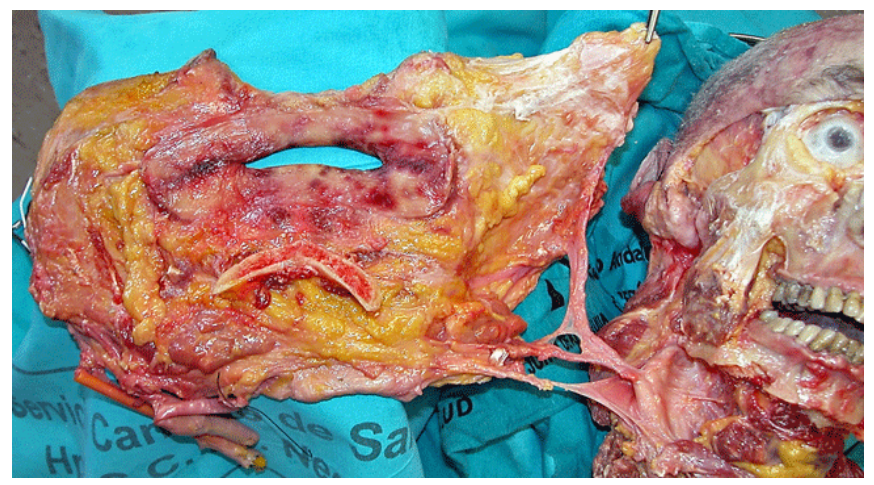

Figure 5: Experimental model of a partial face transplant in cadaver

nerves. This has ensured the full allograft vascularization by preserving muscle-cutaneous perforating vessels between facial muscles and skin component [Figure 4]. ${ }^{[35]}$

FAT design has varied depending on tissue components involved, which determines the extent of each surgical procedure. ${ }^{[36]}$ Most allografts included cheeks, nose, eyelids and lips, and in some cases the tongue and parotid glands have been transferred. At least half of them contained bone (maxilla and/or mandible, including teeth), which requires open osteosynthesis..$^{[37,38]}$

Despite the complexity of the procedure, surgical primary failure has not been documented, which can be explained by head and neck rich vascularisation and the capability of the teams involved in the procedures. ${ }^{[39-41]} \mathrm{A}$ significant blood loss has been described during the procedure requiring transfusions. ${ }^{[42]}$

The restoration of the circulation allograft is achieved with relatively few vascular anastomoses. Most anastomosis was performed in large diameter vessels to minimize the risk of thrombosis. Complete revascularization of the face has proved to be possible from the anastomosis of one vascular pedicle, ${ }^{[43]}$ and vascular viability of the maxilla, palate and mandible..$^{[34]}$ Most teams opted for a bilateral connection of the external carotid or facial arteries. The venous drainage was mainly channeled through the connection of the external jugular, facial or thyrolinguofacial trunk veins [Figure 5]. ${ }^{[44]}$ Almost all anastomoses were performed using conventional end-to-end or end-to-side microsurgical techniques.

Regarding facial nerve neurorrhaphy, some teams have accessed to nerve via parotidectomy, performing the nerve connection at recipient main trunk also including the parotid glands in the allograft. ${ }^{\mid 21]}$ Other teams have performed the anastomosis at peripheral facial nerve branches doing an intra-parotid nerve dissection ${ }^{[45,46]}$ connecting only distal branches to the parotid gland. ${ }^{[1,47]}$ Regarding sensory nerves, most teams connected infraorbital and mental nerves ${ }^{[48-51]}$ while the supraorbital nerve neurorrhaphy is preferably carried out in full FT. ${ }^{[35,36,52,53]}$

\section{PRE-TRANSPLANT CONSIDERATIONS}

In all cases a brain death donor is required besides the consent of the family. Donors and recipients are matched on the basis of race, sex, blood type, human leukocyte antigen and skin color. ${ }^{[54,55]} \mathrm{A}$ full psychological evaluation before including the recipient as a candidate on a FT program is essential. ${ }^{[56]}$ Evident contraindications are psychological disorders that impair the ability of the recipient to follow the immunosuppressive protocol. Informed consent prior to the FT requires a clear understanding of the risks of surgery, immunosuppressive therapy and potential allograft rejection.

\section{Recovery strategy of allograft}

The cold ischemia period since vascular disconnection of allograft from donor until reperfusion is one of the most important aspects as the rapid removal and transference into recipient is required. In the context of a multi-organ donation, most FT teams have removed "the face in the first place" after cardiac arrest and before organ removal. In worldwide experience to date, most of allografts have been removed from beating heart donors in brain dead. In order to reduce cold ischemia period if multiple organ donations, surgical teams prepared the removal procedure by dissecting most of allografts under maintenance of circulation before clamping. ${ }^{.1,39,57-59]}$ If recovery and insertion of allograft are performed in different hospitals, allograft transport should be done in a secure manner in an organ preservation solution, and as quickly as possible to limit the time of ischemia tissues. ${ }^{[60,61]}$

\section{FT indications}

The most common indication was to restore the lower two thirds of the face, especially the perioral and periorbital central zone, including in some cases the forehead, eyelids and scalp, as well as maxilla, mandible and teeth. ${ }^{[62]}$ Inclusion criteria of patients in FT programs vary from one center to another. To date only those patients with extensive tissue damage in which conventional reconstruction procedures previously failed have been included. ${ }^{[49,63,64]}$

Most frequent indications were severe burns (including 
chemical and electrical burns), gunshot trauma, animal bites, plexiform neurofibromas of the trigeminal nerve in the context of neurofibromatosis type I, tumoral sequelae, severe side effects of radiotherapy, vascular tumors, and occupational traumas. However, it must be highlighted that since the first full FT performed in 2010,[43] the spectrum of possible candidates has expanded. In general, patients with significant medical comorbidity, lack of guarantee for post-transplant monitoring, high risk of recurrent cancer under immunosuppression, and pregnancy are excluded. ${ }^{[49]}$ Protocols considered only stable psychological and immunologically patients as potential recipients. ${ }^{[50,56]}$

Patients with plexiform neurofibromas associated with neurofibromatosis type 1 are possible candidates in the absence of viable reconstructive options. To date, 4 patients with neurofibromatosis have undergone FAT. ${ }^{[40,51,55]}$ However, this procedure should still be considered as an experimental option and consequently these patients as well as cancer patients must be carefully selected.

\section{Evolution from partial to full FT}

All FT had been partial before the first full FT which included different aesthetic units of the face (Barcelona, Spain, 2010). ${ }^{[43,65]}$ After the first full FT there was a change in the reconstructive paradigm because of adherence to the classical concepts of facial aesthetic to a FT. From that moment, most FT was complete. This full FT approach has proven effective and safe, and most teams have reported excellent anatomical and functional results. ${ }^{[66-68]}$ Moreover, the restoration of a full new anatomy of the face allowed conventional cosmetic procedures of refinement.

\section{INMUNOLOGY}

The skin is the most important and largest component of FAT, and it is well known that the skin (and the mucosa) has a high immunogenicity, so it is inevitable that rejection episodes are triggered at different times: ${ }^{[33,69]}$ in the early period (hyper-acute rejection), within days or months after transplantation (acute rejection) or chronic rejection. ${ }^{[55,70]}$

Hyper-acute graft rejection has not been reported so far. However, most recipients had acute rejection episodes in the first year, revealed as skin redness, swelling and nodules and papules. ${ }^{[54,71,72]}$ In FAT, episodes of mild rejection may be easier to treat than in solid organ transplantation due to immediate visibility of the skin and easy inspection. Episodes of acute rejection were usually reversible with corticosteroids (bolus treatment), supplemented in some cases by topical drugs (steroids and tacrolimus)..$^{[1,55]}$ Other treatments included the increased tacrolimus levels and topical drugs. ${ }^{[39,50,51,73]}$

For monitoring rejection episodes after transplantation, clinical systematic follow up is required performing skin and/or oral mucosa biopsies. ${ }^{[69,74]}$ In some cases, a sentinel free flap has been transplanted into donor for carrying out multiple biopsies and monitoring of clinical and pathological signs of graft rejection. ${ }^{[1,48]}$

\section{Prevention and treatment of rejection}

Immunosuppressive therapy in patients with FT has been similar to the scheme used in solid organ transplantati on. ${ }^{[43,52,54,66,75]}$ It consisted of an "induction" phase, which starts at an early stage of surgery, followed a "maintenance" phase. Most teams employed an induction therapy with polyclonal anti-thymocyte globulins, monoclonal antibody anti-interleukin-2 receptor as daclizumab and basiliximab, anti-CD3 monoclonal antibodies, mycophenolate mofetil, methylprednisolone, and tacrolimus (anti-calcineurin inhibitor). ${ }^{[76}$ Maintenance and preventing rejection of allograft is based today on the use of a global immunosuppression induction, non-specific, by postoperative triple therapy consisting of the administration of mycophenolate mofetil, tacrolimus and prednisolone. ${ }^{[77]}$

This immunosuppressive regimen should continue during the life of the patient, which carries risks of toxicity and complications like infections (opportunistic infections by cytomegalovirus, herpes, etc.), metabolic (diabetes), nephrotoxicity, hypertension and malignancies. ${ }^{[54]}$ Although theoretically there is a risk of chronic rejection, most teams have not reported evidence of chronic rejection over time. ${ }^{[72,78,79]}$ Recently there is a report of chronic rejection in a patient who left immunosuppression due to a malignant process. $^{[3]}$

\section{New strategies of immunosuppression}

Current research is focused on finding new immunosuppressive molecules that allow adjustment of known drugs and avoid the problems associated with allograft rejection. Research are mainly directed on antibodies anticell-T, the development of more selective molecules with less toxicity to organs (kidney, liver) and creating a state of hematopoietic chimerism. In addition, new immunosuppressant associations are being studied to reduce the doses of each. Some researchers have used bone marrow infusion, thymoglobulin, anti-IL-2 receptor antibody and irradiation of X-rays. Since the skin is the more antigenic portion of allograft, topical treatment with tacrolimus ointment and phototherapy has also been used. ${ }^{[34,80]}$

\section{RESULTS AND COMPLICACIONS}

\section{Functional and aesthetic results}

FT aims to re-establish the functions of speaking, swallowing and mimic muscle mobility as well as to provide aesthetic improvements that allow patients to live a normal social life. Although a systematic analysis of all cases cannot be performed due to the unique characteristics of each patient, the results of the earliest FT, as a whole, are very convincing. ${ }^{[81]}$

Unlike solid organ transplants, in which a metabolic 
function after revascularization of the organ is immediately detected, the FAT is initially viable after reperfusion in the operating room, but facial motor activity and sensitivity are absent. Therefore, in the first months of follow up, nerve regeneration and muscle rehabilitation becomes a challenge as well as patient's ability to reintegrate allograft in sensory and motor cortex in the central nervous system. Between 6-9 months, patients recovered discriminative sensitivity of the face. The recovery of active and passive movements of the lips was obtained between 6 and 12 months, but results differed between full or partial FT. ${ }^{[45,48,54,57]}$ The functional improvements have been proportional to motor recovery, reaching even in some cases to restoration of near normal functional capacity. ${ }^{[72]}$

The long-term results are yet to be assessed and reported by different FT teams and therefore a final assessment of the results cannot be offered now. ${ }^{[82]}$ Almost all patients have been able to breathing through the nose, smelling, chewing, swallowing, eating and speech and phonation recovering to a greater or lesser extent. ${ }^{[50,55,63,82-84]}$

\section{Psycho-social outcomes}

Psychological long-term results are not known with accuracy because the novel nature of the procedure, although preliminary results have reported positive outcomes. In general, patients experienced an acceptable improvement of quality of life with social reintegration and meaningful changes for having recovered their body image, without psychological disorders. ${ }^{[0,63]}$ All patients have accepted their new face and some patients returned to work. ${ }^{[45,53,72]}$ The favorable outcome is probably a consequence of the strict preoperative selection with a psychiatric and psychological evaluation of motivated and compliant patients. ${ }^{[85-87]}$

After the inset of the donor face on the recipient, no problems were detected with regard to identity transfer or change in body image in FT recipients. What is obtained is a mixture of both subjects, and due to differences in the characteristics of each facial bony structures, a new face is formed. Therefore, the initial concerns about appearance of feelings of depersonalization to the new face and the transfer or separation of the donor's identity have not been substantiated. According to donor families, recipients and transplant teams, the recipients do not resemble the donor. ${ }^{[72,88,89]}$

\section{Post-transplant revisions and refinements}

To the extent that the number of FT has increased, various surgical refinements have been planned to optimize the aesthetic and functional results. ${ }^{[30,90]}$ The functional and aesthetic improvement can be supported in various secondary procedures as such as the re-alignment of the jaws, restoration of teeth, re-suspension of the soft tissues, fat injections and dermabrasion. ${ }^{[91-95]}$ These revisions did not seem to have caused major complications or affected in any way the immunological rejection. ${ }^{[40]}$

\section{Post-trasplant complicacions}

Despite the complexity of the procedure, no cases of allograft loss by surgical failures, such as arterial or venous thrombosis or tissue damage by cold ischemia time, have been reported. The most important complications derived from immunosuppressive therapy and drug toxicity leading to metabolic disorders, opportunistic infections and increased incidence of malignancy. Tacrolimus, a potent calcineurin inhibitor, is well known for its severe nephrotoxicity. ${ }^{[63]}$ The majority of patients have suffered from opportunistic infections such as cytomegalovirus, herpes simplex, herpes zoster, candida albicans and bacterial infections, most of them have been treated successfully. ${ }^{[55,75]}$ Due to an increased risk of carcinogenesis in the context of a suppressed immune system, it was likely that a correlation between immunosuppressive medication and the appearance of tumors was established. In this sense, neurofibromatosis type 1 or post-oncological sequelae are indications that may be critically questioned. Finally, at least 5 deaths associated with the FT procedure have been collected so far caused by failure of the immunotherapeutic regime, sepsis, recurrent malignant tumor, multiple organ failure and suicide, ${ }^{[34,96]}$ which for some researchers reopens the question of risk versus benefit in the FT. ${ }^{[3,97]}$

\section{ETHICAL IMPLICATIONS}

From the ethical point of view, a crucial issue widely discussed in the literature has been the obligation to subject individuals to immunosuppressive treatment during patient's life, leading to increased risk of developing complications, ${ }^{[33]}$ when it is not a procedure to "save lives", unlike solid organ transplant that often have an urgent indication to save a person life. From that point of view, the risks of immunosuppressive therapy may outweigh the benefits of the procedure due to recipients are exposing to the risks of immunosuppression. However, all transplant teams have reported that the reestablishment of the functional capabilities and the restoration of the face "have changed the lives of patients", and a significant improvement in patient's quality of life has occurred. ${ }^{[45]}$

An ethical unsolved problem would arise if a total loss allograft occurs as a result of a surgical complication or irreversible rejection. ${ }^{[55]}$ Confronted with this catastrophic situation, very few reconstructive options would remain for that patient ${ }^{[54]}$ and hypothetically, patients would return to a starting situation much worse as consequence of the procedure FAT.

Informed consent is crucial before performing a FAT for the reasons discussed above. Moreover, the question has arisen whether consent can be truly informed if the candidate previously does not coexist with the facial disfigurement for some time. Something as outlined in breast reconstruction, where a period of post-mastectomy waiting gives the woman the opportunity to accept a complex reconstruction. ${ }^{[98]}$ Pediatric age creates an ethical 
dilemma since it is linked to the difficulty of obtaining informed children consent, psychological instability during the years of growth, risk of cancer and complications of immunosuppression throughout a long life ahead. Another aspect to consider is the high economic costs of $\mathrm{FT}^{[54,99]}$ both the procedure and the immunosuppressive lifetime therapy, preventing its widespread application and opens the discussion of opportunity-cost for countries with public health services. ${ }^{[54,99]}$

\section{FUTURE DIRECTIONS}

From the first FT performed a decade ago, more than thirty FAT have been performed worldwide with promising immunological, functional, psychological and aesthetic results that have clearly demonstrated the feasibility of this demanding process. Unlike solid organ transplant that "potentially saved a life", what FAT provides is a "change of life" to recipients. This substantial difference has created ethical concerns in society about the exposure of individuals (young and otherwise healthy) to potential immunological complications and the ability to provide informed consent. On the other hand, the incessant advance in microsurgical techniques and the computer assisted surgical planning, have progressively allowed a broader clinical application of this procedure, and have promoted the evolution from the first partial FT to full procedures of FT. All these are on the basis of accurate and careful selection of well-motivated candidates. There is a firm belief in the scientific community that, at present, surgical innovations in the field of FT have overcome to some extent immune, medical and ethical aspects. However, FT is still an experimental procedure in which we have much to learn. Next challenge will be getting new strategies for more effective immunosuppressive therapy and improved donor-specific tolerance. There are still unresolved problems and crucial aspects to define the true role of the FAT in the current reconstructive surgery.

\section{Financial support and sponsorship}

Nil.

\section{Conflicts of interest}

There are no conflicts of interest.

\section{REFERENCES}

I. Devauchelle B, Badet L, Lengelé B, Morelon E, Testelin S, Michallet M, D'Hauthuille C, Dubernard JM. First human face allograft: early report. Lancet 2006;368:203-9.

2. Roche NA, Blondeel PN, Van Lierde KM, Vermeersch HF. Facial transplantation: history and update. Acta Chir Belg 20I5; I 15:99-103.

3. Wo L, Bueno E, Pomahac B. Facial transplantation: worth the risks? A look at evolution of indications over the last decade. Curr Opin Organ Transplant 2015;20:615-20.

4. Siemionow M, Unal S, Agaoglu G, Sari A. A cadaver study in preparation for facial allograft transplantation in humans: part I. What are alternative sources for total facial defect coverage? Plast Reconstr Surg 2006; I 17:86472.

5. Meningaud JP, Paraskevas A, Ingallina F, Bouhana E, Lantieri L. Face transplant graft procurement: a preclinical and clinical study. Plast Reconstr Surg 2008; $122: 1383-9$.
6. Silverman RP, Banks ND, Detolla LJ, Shipley ST, Panda A, Sanchez RA, Azimzadeh AM, Pierson RN 3rd, Wang D, Rodriguez ED, Holton LH 3rd, Bartlett ST. A heterotopic primate model for facial composite tissue transplantation. Ann Plast Surg 2008;60:209-16.

7. Barth RN, Bluebond-Langner R, Nam A, Stanwix M, Shipley S, Bartlett ST, Rodriguez ED. Facial subunit composite tissue allografts in nonhuman primates I. Technical and functional requirements for prolonged graft survival. Plast Reconst Surg 2009; I23:493-50I.

8. Kuo YR, Shih HS, Lin CC, Huang CC, Yang JC, Wu WS, Goto S, Chen CL, Lee WP. Swine hemi-facial composite tissue allotrasplantation: a model to study immune rejection.J Surg Res 2009;153:268-73.

9. Baek RM, Eun SC, Heo CY, Chang H. Experimental facial transplantation surgery. J Craniofac Surg 2010;21:648-5I.

10. Ulusal BG, Ulusal AE, Ozmen S, Zins JE, Siemionow MZ.A new composite facial and scalp transplantation model in rats. Plast Reconst Surg 2003; I I2:1302-II.

II. Landin L, Cavadas PC. The mystacial pad flap: a functional facial flap in rats. Ann Plast Surg 2005;56:107-8.

12. Yazici I, Carnevale K, Klimczak A, Siemionow M. A new rat model of maxilla allotransplantation. Ann Plast Surg 2007;58:338-44.

13. Landin L, Cavadas PC, Gonzalez E, Rodriguez JC, Caballero A. Funcional outcome after facial allograft transplantation in rats. J Plast Reconst Aesth Surg 2008;61:1034-43.

14. Kulahci Y, Siemionow M. A new composite hemiface/mandible/tongue transplantation model in rats. Ann Plast Surg 2010;64:1 | 4-21.

15. Liu Q, Li Q, Zheng S, Zheng D. Preservation of canine composite facial flaps using UW solution. Arch Facial Plast Surg 2010;12:263-8.

16. Yu D, Li Q, Zheng S, Wang H, Liu Q. Some results of our research on composite tissue transplantation in dogs. Transplant Proc 2010;42:1953-5.

17. Yazici I, Unal S, Siemionow M. Composite hemiface/calvaria transplantation model in rats. Plast Reconst Surg 2011;118:1321-7.

18. Ramirez AE, Lao WW, Wang YL, Cheng HY, Wei FC. Two-stage face transplantation: a new concept in vascularized composite allotransplantation. Microsurgery 2015;35:218-26.

19. Siemionow M, Agaoglu G, Unal S. A cadaver study in preparation for facial allograft transplantation in humans: part II. Mock facial transplantation. Plast Reconstr Surg 2006; I 17:876-85.

20. Lengelé BG. Current concepts and future challenges in facial transplantation. Clin Plast Surg 2009;36:507-2I.

21. Meningaud JP, Benjoar MD, Hivelin M, Hermeziu O, Toure G, Lantieri L. Procurement of total human face graft for allotransplantation: a preclinical study and the first clinical case. Plast Reconstr Surg 20 I0; I 26: I I I -90.

22. Gordon CR, Susarla SM, Peacock ZS, Cetrulo CL, Zins JE, Papay F, Kaban LB, Yaremchuk MJ. Osteocutaneous maxillofacial allotransplantation: lessons learned from a novel cadaver study applying orthognathic principles and practice. Plast Reconstr Surg 20I I; I 28:465-79.

23. Meningaud JP, Hivelin M, Benjoar MD, Toure G, Hermeziu O, Lantieri L. The procurement of allotransplants for ballistic trauma: a preclinical study and a report of two clinical cases. Plast Reconstr Surg 201 I; 127:1892-900.

24. Gastman B, Djohan R, Siemionow M. Extending the Cordeiro maxillofacial defect classification system for use in the era of vascularized composite transplantation. Plast Reconstr Surg 2012;130:419-22.

25. Baccarani A, Follmar KE, Erdmann D, Levin LS. Face transplantation surgical options and open problems in cadaveric models: a review article. Microsurgery 20I3;33:239-46.

26. Mohan R, Borsuk DE, Dorafshar AH, Wang HD, Bojovic B, Christy MR, Rodriguez ED.Aesthetic and functional facial transplantation: a classification system and treatment algorithm. Plast Reconstr Surg 20|4; |33:386-97.

27. Rudman K, Hoekzema C, Rhee J. Computer-assisted innovations in craniofacial surgery. Facial Plast Surg 20I I;27:358-65.

28. Brown EN, Dorafshar AH, Bojovic B, Christy MR, Borsuk DE, Kelley TN, Shaffer CK, Rodriguez ED. Total face, double jaw, and tongue transplant simulation: a cadaveric study employing computer-assisted techniques. Plast Reconstr Surg 2012;130:815-23.

29. Caterson EJ, Diaz-Siso JR, Shetye P, Junker JP, Bueno EM, Soga S, Rybicki FJ, Pomahac B. Craniofacial principles in face transplantation. J Craniofac Surg 2012;23:1234-8.

30. Jacobs JM, Dec W, Levine JP, McCarthy JG, Weimer K, Moore K, Ceradini DJ. Best face forward: virtual modeling and custom device fabrication to optimize craniofacial vascularized composite allotransplantation. Plast Reconstr Surg 2013;131:64-70.

31. Caterson EJ. Future directions for face transplantation. J Craniofac Surg 
$20 \mid 4 ; 25: 3-5$

32. Fernandez-Alvarez JA, Infante-Cossio P, Barrera-Pulido F, GactoSanchez P, Suarez-Mejias C, Gomez-Ciriza G, Sicilia-Castro D, GomezCia T. Virtual reality AYRA software for preoperative planning in facial allotransplantation.J Craniofac Surg 20 I4;25: I805-9.

33. Petruzzo P, Kanitakis J, Badet L, Pialat JB, Boutroy S, Charpulat R, Mouly J, Gazarian A, Lanzetta M, Brunet M, Devauchelle B, Testelin S, Martin $X$, Dubernard JM, Morelon E. Long-term follow-up in composite tissue allotransplantation: in-depth study of five (hand and face) recipients. Am J Transplant 2011;11:808-16.

34. Shanmugarajah K, Hettiaratchy S, Clarke A, Butler PE. Clinical outcomes of facial transplantation: a review. Int J Surg 201 I;9:600-7.

35. Pushpakumar SB, Barker JH, Soni CV, Joseph H, van Aalst VC, Banis JC, Frank J. Clinical considerations in face transplantation. Burns 2010;36:95I8.

36. Hui-Chou HG, Nam AJ, Rodriguez ED. Clinical facial composite tissue allotransplantation: a review of the first four global experiences and future implications. Plast Reconstr Surg 2010;125:538-46.

37. Smeets R, Rendenbach C, Birkelbach M, Al-Dam A, Gröbe A, Hanken H, Heiland $M$. Face transplantation: on the verge of becoming clinical routine? Biomed Res Int 2014;2014:907272.

38. Özel AȘ, Güçlü ZA, Gülșen A, Özmen S. The Importance of the condition of the donor teeth and jaws during allogeneic face transplantation. J Craniofac Surg 2015;26:1338-4I.

39. Guo S, Han Y, Zhang X, Lu B, Yi C, Zhang H, Ma X, Wang D, Yang L, Fan X, Liu Y, Lu K, Li H. Human facial allotransplantation: a 2-year follow-up study. Lancet 2008;372:63I-8.

40. Lantieri L, Meningaud JP, Grimbert P, Bellivier F, Lefaucheur JP, Ortonne N, Benjoar MD, Lang P,Wolkenstein P. Repair of the lower and middle parts of the face by composite tissue allotransplantation in a patient with massive plexiform neurofibroma: a I-year follow-up study. Lancet 2008;372:639-45.

41. Gomez-Cia T, Sicilia-Castro D, Infante-Cossio P, Barrera-Pulido F, Gacto-Sanchez P, Lagares-Borrego A, Narros-Gimenez R, Garcia-Perla A, Hernandez-Guisado JM, González-Padilla JD. Second human facial allotransplantation to restore a severe defect following radical resection of bilateral massive plexiform neurofibromas. Plast Reconstr Surg 20II;I 27:995-6.

42. Hinojosa Pérez R, Porras López M, Escoresca-Ortega AM, Herruzo Avilés A, León A, Noval JA, Gómez-Cía T, Sicilia D, González Padilla JD. Severe rhabdomyolysis after allogeneic transplantation of facial structures: a case report. Transplant Proc 2010;42:3081-2.

43. Barret JP, Gavaldà J, Bueno J, Nuvials X, Pont T, Masnou N, Colomina MJ, Serracanta J, Arno A, Huguet P, Collado JM, Salamero P, Moreno C, Deulofeu R, Martínez-lbáñez V. Full face transplant: the first case report. Ann Surg 201 I;254:252-6.

44. Infante-Cossio P, Sicilia-Castro D, Gomez-Cia T. Comment on: "Twostage face transplantation: a new concept in vascularized composite allotransplantation”. Microsurgery 20I5;35:4 I 9-20.

45. Pomahac B, Pribaz J, Eriksson E, Bueno EM, Diaz-Siso JR, Rybicki FJ, Annino DJ, Orgill D, Caterson EJ, Caterson SA, Carty MJ, Chun YS, Sampson CE, Janis JE, Alam DS, Saavedra A, Molnar JA, Edrich T, Marty FM, Tullius SG. Three patients with full facial transplantation. N Engl J Med 2012;366:7 I522.

46. Khalifian S, Brazio PS, Mohan R, Shaffer C, Brandacher G, Barth RN, Rodriguez ED. Facial transplantation: the first 9 years. Lancet 2014;384:2 I 5363.

47. Cavadas PC, Ibáñez J, Thione A. Surgical aspects of a lower face, mandible, and tongue allotransplantation.J Reconstr Microsurg 20I2;28:43-7.

48. Dubernard JM, Lengelé B, Morelon E, Testelin S, Badet L, Moure C, Beziat JL, Dakpé S, Kanitakis J, D'Hauthuille C, El Jaafari A, Petruzzo P, Lefrancois N, Taha F, Sirigu A, Di Marco G, Carmi E, Bachmann D, Cremades S, Giraux P, Burloux G, Hequet $O$, Parquet N, Francès C, Michallet M, Martin X, Devauchelle B. Outcomes 18 months after the first human partial face transplantation. N Engl J Med 2007;357:245 I-60.

49. Pomahac B, Diaz-Siso JR, Bueno EM. Evolution of indications for facial transplantation.J Plast Reconstr Aesthet Surg 201 I;64:1410-6.

50. Pomahac B, Pribaz J, Eriksson E, Annino D, Caterson S, Sampson C, Chun Y, Orgill D, Nowinski D, Tullius SG. Restoration of facial form and function after severe disfigurement from burn injury by a composite facial allograft. Am J Transplant 201 I; I I:386-93.

5I. Sicilia-Castro D, Gomez-Cia T, Infante-Cossio P, Gacto-Sanchez P, Barrera-Pulido F, Lagares-Borrego A, Narros-Gimenez R, Garcia-Perla A,
Hernandez-Guisado JM, Gonzalez-Padilla JD. Reconstruction of a severe facial defect by allotransplantation in neurofibromatosis type I: a case report. Transplant Proc 201 I;43:2831-7.

52. Shanmugarajah K, Hettiaratchy S, Butler PE. Facial transplantation. Curr Opin Otolaryngol Head Neck Surg 2012;20:291-7.

53. Singhal D, Pribaz J], Pomahac B. The Brigham and Women's Hospital face transplant program: a look back. Plast Reconstr Surg 20।2;।29:e8।-8.

54. Siemionow M, Ozturk C. Face transplantation: outcomes, concerns, controversies, and future directions. J Craniofac Surg 2012;23:254-9.

55. Infante-Cossio P, Barrera-Pulido F, Gomez-Cia T, Sicilia-Castro D, GarciaPerla-Garcia A, Gacto-Sanchez P, Hernandez-Guisado JM, Lagares-Borrego A, Narros-Gimenez R, Gonzalez-Padilla JD. Facial transplantation: a concise update. Med Oral Patol Oral Cir Bucal 2013;18:e263-7I.

56. Lantieri L. Face transplant: a paradigm change in facial reconstruction. J Craniofac Surg 2012;23:250-3.

57. Siemionow M, Papay F,Alam D, Bernard S, Djohan R, Gordon C, Hendrickson M, Lohman R, Eghtesad B, Coffman K, Kodish E, Paradis C, Avery R, Fung J. Near-total human face transplantation for a severely disfigured patient in the USA. Lancet 2009;374:203-9.

58. Bueno J, Barret JP, Serracanta J, Arnó A, Collado JM, Valles C, Colominas MJ, Diez Y, Pont T, Salamero P, Martinez-lbañez V. Logistics and strategy of multiorgan procurement involving total face allograft. Am J Transplant 2011;11:1091-7.

59. Gomez-Cia T, Infante-Cossio P, Sicilia-Castro D, Gacto-Sanchez P, Gonzalez-Padilla JD. Sequence of multiorgan procurement involving face allograft. Am J Transplant 201 I; I I:226I.

60. Pomahac B, Papay F, Bueno EM, Bernard S, Diaz-Siso JR, Siemionow M. Donor facial composite allograft recovery operation: Cleveland and Boston experiences. Plast Reconstr Surg 2012; 1 29:e46I-7.

61. Siemionow M, Ozturk C. An update on facial transplantation cases performed between 2005 and 2010. Plast Reconstr Surg 20I I;I 28:e707-20.

62. Gordon CR, Susarla SM, Peacock ZS, Kaban LB, Yaremchuk MJ. Le Fortbased maxillofacial transplantation: current state of the art and a refined technique using orthognathic applications. J Craniofac Surg 20I 2;23:8I-7.

63. Lantieri L, Hivelin M, Audard V, Benjoar MD, Meningaud JP, Bellivier F, Ortonne N, Lefaucheur JP, Gilton A, Suberbielle C, Marty J, Lang P, Grimbert P. Feasibility, reproducibility, risks and benefits of face transplantation: a prospective study of outcomes. Am J Transplant 201 I; I I:367-78.

64. Iglesias M, Butrón P, Osuna-Leal Al, Abarca-Perez L, Sosa-Ascencio MJ, Moran-Romero MA, Cruz-Reyes AU, Pineda-Gutierrez FJ, LeonLopez DA, García-Alvarez MN, Alberu J, Vilatoba M, Leal-Villalpando RP, Zamudio-Bautista J, Acosta-Nava VM, Gonzalez J. Is Mexico ready for face transplantation? Transplant Proc 2015;47:1998-2002.

65. Barret JP, Serracanta J, Collado JM, Garrido A, Salamero P, Pont T, Masnou N, Arana E, Arno A, Garcia V, Sancho J, Ruiz M. Full face transplantation organization, development, and results-the Barcelona experience: a case report. Transplant Proc 20I I;43:3533-4.

66. Bojovic B, Dorafshar AH, Brown EN, Christy MR, Borsuk DE, Hui-Chou HG, Shaffer CK, Kelley TN, Sauerborn PJ, Kennedy K, Hyder M, Brazio PS, Philosophe B, Barth RN, Scalea TM, Bartlett ST, Rodriguez ED. Total face, double jaw, and tongue transplant research procurement: an educational model. Plast Reconstr Surg 2012;130:824-34.

67. Pomahac B, Pribaz JJ, Bueno EM, Sisk GC, Diaz-Siso JR, Chandawarkar A, Westvik TS, Malin EW, Eriksson E. Novel surgical technique for full face transplantation. Plast Reconstr Surg 2012; I30:549-55.

68. Pomahac B, Bueno EM, Sisk GC, Pribaz JJ. Current principles of facial allotransplantation: the Brigham and Women's Hospital experience. Plast Reconstr Surg 2013;131:1069-76.

69. Kanitakis J, Badet L, Petruzzo P, Béziat JL, Morelon E, Lefrançois N, Françès C, Claudy A, Martin X, Lengelé B, Testelin S, Devauchelle B, Dubernard JM. Clinicopathologic monitoring of the skin and oral mucosa of the first human face allograft: report on the first eight months. Transplantation 2006;82:1610-5

70. Alam DS, Papay F, Djohan R, Bernard S, Lohman R, Gordon CR, Hendrickson $M$, Siemionow M. The technical and anatomical aspects of the World's first near-total human face and maxilla transplant. Arch Facial Plast Surg 2009; I I:369-77.

7I. Fischer S, Lian CG, Kueckelhaus M, Strom TB, Edelman ER, Clark RA Murphy GF, Chandraker AK, Riella LV, Tullius SG, Pomahac B. Acute rejection in vascularized composite allotransplantation. Curr Opin Organ Transplant 2014;19:531-44.

72. Petruzzo P, Testelin S, Kanitakis J, Badet L, Lengelé B, Girbon JP, Parmentier 
$\mathrm{H}$, Malcus C, Morelon E, Devauchelle B, Dubernard JM. First human face transplantation: 5 years outcomes. Transplantation 2012;93:236-40.

73. Siemionow MZ, Papay F, Djohan R, Bernard S, Gordon CR, Alam D, Hendrickson M, Lohman R, Eghtesad B, Fung J. First U.S. near-total human face transplantation: a paradigm shift for massive complex injuries. Plast Reconstr Surg 2010; I 25: I I I-22.

74. Chaudhry A, Sosin M, Bojovic B, Christy MR, Drachenberg CB, Rodriguez ED. Defining the role of skin and mucosal biopsy in facial allotransplantation: a 2-year review and analysis of histology. Plast Reconstr Surg 2015; 136:559. 67.

75. BenMarzouk-Hidalgo OJ, Cordero E, Gómez-Cía T, Sánchez M, GonzálezPadilla JD, Infante-Cossio P, Sicilia-Castro D, Hernández-Guisado JM, PérezRomero P. First face composite-tissue transplant recipient successfully treated for cytomegalovirus infection with preemptive valganciclovir treatment. Antimicrob Agents Chemother 201 I;55:5949-5I.

76. Whitaker IS, Duggan EM, Alloway RR, Brown C, McGuire S, Woodle ES, Hsiao EC, Maldonado C, Banis JC Jr, Barker JH. Composite tissue allotransplantation: a review of relevant immunological issues for plastic surgeons. J Plast Reconstr Aesthet Surg 2008;61:481-92.

77. Siemionow M, Madajka M, Cwykiel J.Application of cell-based therapies in facial transplantation. Ann Plast Surg 2012;69:575-9.

78. Wu S, Xu H, Ravindra K, Ildstad ST. Composite tissue allotransplantation: past, present and future-the history and expanding applications of CTA as a new frontier in transplantation. Transplant Proc 2009;4I:463-5.

79. Unadkat JV, Schneeberger S, Horibe EH, Goldbach C, Solari MG,Washington KM, Gorantla VS, Cooper GM, Thomson AW, Lee WP. Composite tissue vasculopathy and degeneration following multiple episodes of acute rejection in reconstructive transplantation. Am JTransplant 20 10;10:25 I-6I.

80. Garrett GL, Beegun I, D'souza A. Facial transplantation: historical developments and future directions. J Laryngol Otol 20I5; I 29:206-I I.

8I. Fischer S, Kueckelhaus M, Pauzenberger R, Bueno EM, Pomahac B. Functional outcomes of face transplantation. Am J Transplant 20 I5; 15:22033

82. Westvik TS, Dermietzel A, Pomahac B. Facial restoration by transplantation: the Brigham and Women's face transplant experience. Ann Plast Surg 2015;74 SupplI:S2-8

83. Lierde KM, Roche N, Letter MD, Corthals P, Stillaert F, Vermeersch H, Blondeel P. Speech characteristics one year after first Belgian facial transplantation. Laryngoscope 2014; I24:202 I-7.

84. Roche NA, Vermeersch HF, Stillaert FB, Peters KT, De Cubber J,Van Lierde K, Rogiers X, Colenbie L, Peeters PC, Lemmens GM, Blondeel PN. Complex facial reconstruction by vascularized composite allotransplantation: the first Belgian case.J Plast Reconstr Aesthet Surg 2015;68:362-7I.
85. Johnson SE, Corsten MJ. Facial transplantation in a new era: what are the ethical implications? Curr Opin Otolaryngol Head Neck Surg 2009; 17:274-8.

86. Siemionow MZ, Gordon CR. Institutional review board-based recommendations for medical institutions pursuing protocol approval for facial transplantation. Plast Reconstr Surg 2010; 126:1232-9.

87. Soni CV, Barker JH, Pushpakumar SB, Furr LA, Cunningham M, Banis JC Jr, Frank J. Psychosocial considerations in facial transplantation. Burns 2010;36:959-64.

88. Coffman KL, Gordon C, Siemionow M. Psychological outcomes with face transplantation: overview and case report. Curr Opin Organ Transplant 2010;15:236-40.

89. Coffman KL, Siemionow MZ. Face transplantation: psychological outcomes at three-year follow-up. Psychosom 2013;54:372-8.

90. Dorafshar AH, Bojovic B, Christy MR, Borsuk DE, lliff NT, Brown EN, Shaffer CK, Kelley TN, Kukuruga DL, Barth RN, Bartlett ST, Rodriguez ED. Total face, double jaw, and tongue transplantation: an evolutionary concept. Plast Reconstr Surg 2013; |31:24 |-5 |.

91. Meningaud JP, Donsimoni JM, Lantieri L. Facial allograft transplantation and basal implantology (cortically anchored disk-design implants). Rev Stomatol Chir Maxillofac 2009; I 10:353-8.

92. Fisher M, Dorafshar A, Bojovic B, Manson PN, Rodriguez ED.The evolution of critical concepts in aesthetic craniofacial microsurgical reconstruction. Plast Reconstr Surg 2012;130:389-98.

93. Barret JP, Serracanta J. LeFort I osteotomy and secondary procedures in full-face transplant patients. J Plast Reconstr Aesthet Surg 20I3;66:723-5.

94. Diaz-Siso JR, Parker M, Bueno EM, Sisk GC, Pribaz JJ, Eriksson E, Annino D, Tullius SG, Pomahac B. Facial allotransplantation: a 3-year follow-up report. J Plast Reconstr Aesthet Surg 20 I 3;66: I 458-63.

95. Mohan R, Fisher M, Dorafshar A, Sosin M, Bojovic B, Gandhi D, Iliff N, Rodriguez ED. Principles of face transplant revision: beyond primary repair. Plast Reconstr Surg 2014; I34:1295-304.

96. Carty MJ, Hivelin M, Dumontier C, Talbot SG, Benjoar MD, Pribaz JJ, Lantieri L, Pomahac B. Lessons learned from simultaneous face and bilateral hand allotransplantation. Plast Reconstr Surg 2013;132:423-32.

97. Coffman KL, Siemionow MZ. Ethics of facial transplantation revisited. Curr Opin Organ Transplant 2014;19:181-7.

98. Gharb B, Rampazzo A, Hakki S, Madajka M, Cwykiel J, Stratton J, Siemionow MZ. Effectiveness of topical immunosuppressants in prevention and treatment of rejection in face allotransplantation. Transplantation 2013;95:1197-203.

99. Rüegg EM, Hivelin M, Hemery F, Maciver C, Benjoar MD, Meningaud JP, Lantieri L. Face transplantation program in France: a cost analysis of five patients. Transplantation 2012;93: I 166-72. 